DOI:10.30842/ielcp230690152326

A. Eseleva

(Institute for Linguistic Studies, RAS, St. Petersburg)

\title{
CORRELATIVE CAUSAL CLAUSES IN THE OLD ENGLISH BOETHIUS ${ }^{1}$
}

The paper focuses on correlative clauses with causal connector forpam in the text of the Old English translation of Boethius's treatise De Consolatione Philosophiae. The text is rich in forpam-clauses but correlative clauses only account for 15 per cent of the overall use of forpam.

Keywords. Old English Boethius, translation, correlative clauses, causality.

А. А. Еселева

(Институт лингвистических исследований РАН, Санкт-Петербург)

\section{Коррелятивные структуры с каузальным значением в древнеанглийском переводе De Consolatione Philosophiae Боэция}

В статье рассматриваются коррелятивные структуры с каузальным значением, образуемые в древнеанглийском языке при помощи местоименного коннектора forpam. Выступая в главном предложении в функции наречия, а в придаточном - в функции подчинительного союза, данный коннектор формирует коррелятивную связь между клаузами. Помимо этого, forpam в качестве наречия в главном предложении связывает его с предшествующими аргументами, поддерживая целостность линии рассуждения.

Ключевые слова: древнеанглийский перевод De Consolatione Philosophiae Боэция, коррелятивные структуры с каузальным значением.

Correlation in Old English (OE) as well as in other ancient IndoEuropean languages is widespread, and, according to Mitchell, represents «a natural corollary of the move from parataxis to hypotaxis» (Mitchell 1985, vol. I, § 1894). This paper focuses on just one type of correlation - that between causal clauses in a single text, the Old English Boethius, where causal relations play a prominent role. The Old English Boethius is a free translation of Boethius's treatise De Consolatione Philosophiae and the first and only piece of philosophical writing in OE.

Causal relations are most commonly introduced in $\mathrm{OE}$ with the lexical item forpam consisting of the preposition for and a case-

\footnotetext{
${ }^{1}$ The research was supported by RSF grant No. 17-18-01624.
} 
marked form of the demonstrative se. Two case forms, dative and instrumental, and their spelling variants create certain diversity attested in the text: forpam, fordam, and forpam for the dative, forpon, forpy, forðy, and forpi for the instrumental, to list just most common variants. The process of grammaticalization is not yet complete. The following examples illustrate the use of the preposition plus the demonstrative within one sentence with the use of forpam as one lexical item functioning as subordinator:

(1) For bam pingum wæs gio pæt se wisa Catulus hine gebealg and swa ungefræglice forcwæð Nonium pone rican, forbam he hine gemette sittan on gerenedum scridwæne (27.14).

'For those reasons was it long ago that the wise Catulus became angry and insulted Nonius the man of high position in such an unheard-of manner, because he met him sitting on a decorated chariot' ${ }^{2}$.

For decades, it has been discussed in the literature whether definite distinctions between subordinating and coordinating functions of forpam can be established. Mitchell (1985) describes forpam as «ambiguous adverb/conjunction». Kortmann (1997: 292) characterizes it as «an item of unclear status», which does not meet the criteria for «ideal» adverbial subordinator. Lenker (2007) adopts the term 'all-purpose causal and resultative pronominal connector'. Whenever forbam appears with the particle $p e$, it certainly functions as a subordinator, however, the use of forpam vs. forpam pe is inconsistent, cf. example (2):

(2) Hwæt ealle men hæfdon gelicne fruman forbam hi ealle coman of anum fæder and of anre meder, and ealle hi beoð git gelice acennede. Nis pæt nan wundor forbam pe an God is fæder eallra gesceafta forpam he hi ealle gesceop and ealra welt (30.38).

'Truly, all people had the same origin for they all came from one father and from one mother, and they are all born alike. That is no wonder, for one God is father of all creatures, for he created them all and rules them all'.

All three instances in the example above illustrate subordinative use of forpam/ forpam pe. The second and the third subordinator in example (2) are used consecutively but do not correlate. Each of

\footnotetext{
${ }^{2}$ Both Old English examples and their Present-Day English translations in this paper are from the edition by Godden \& Irvine 2009. The study is based on Text B of the Old English Boethius. Reference is given by chapter and line.
} 
them introduces explanation for the idea stated in the previous clause. Adverbial use of forpam is exemplified in (3):

(3) Leorniað forpam wisdom (16.33). 'Learn wisdom therefore'.

As an adverb, forpam tends to be located clause-initially, and provides a link in the line of argument.

The correlative structure studied here involves two immediately following forpam-clauses, in which one forpam is a coordinator, and the other - a subordinator. The linear order of the clauses may vary. Examples (4) and (5) illustrate both possible options:

(4) forbam ne mæg non mon nænne cræft forðbringan buton wisdom, forpam be swa hwæt swa purh dysige gedon bip ne mæg hit mon næfre to cræfte gerecan (17.23).

'for no-one can bring forth any art without wisdom, for whatever is done through folly can never be accounted a skill';

(5) and forpy pe hi nan gecyndelic god on him selfum nabbað, forby hi losiað swa swa sceadu oððe smec (27.77).

'and because they have no natural good in themselves, they disappear like a shadow or smoke'.

The Old English Boethius contains 32 structures of this type. This roughly corresponds to 15 per cent of all instances of forpam in the text. Commonly the main clause precedes the subordinate clause: there are 25 structures of the type exemplified in (4), and 7 structures of the type illustrated in (5). Subordinate forpam-clauses generally tend to follow the main clause, also when there is no correlation. However, this linear order in correlative structures seems to have additional function: when the main clause with an adverb in clause-initial position precedes the subordinate clause, this adverb has double reference, cf.:

(6) swa pætte pæt on oðrum lande betst licað pætte pæt bið hwilum on ðam oðrum tælwyrðlicost and eac micelles wites wyrðe. Forðam ne mæg nan mon habban gelic lof on ælcum londe, forbon ðe on ælcum lande ne licað pæt on oðrum licað (18.68)

'so that what pleases best in one country is sometimes most disapproved of in the others and also deserving of great punishment. For no-one can have similar praise in every country, for in each country they don't like what they like in others'.

Not only does it correlate to the subordinating forpam that follows but also refers 'backwards', summarizing the ideas presented earlier and thus performing its main linking function. 
Though forpam is the main causal connector in OE, there are other means as well, such as subordinator $p y$ 'because'. It can form a correlative structure with forpam, too. Examples like (7) are rare: there are only two such instances out of 32.

(7) forpi he eac wilnað pæt he habbe pæt he næfð, py he wolde genog habban (26.35).

'the reason why he also seeks to have what he does not have is that he would like to have enough'.

There does not seem to be a correspondence between the case marking of the 'pronominal connector' and its place within the correlative structure. Out of 32 adverbs, 19 are in the dative vs. 13 in the instrumental. Out of 30 subordinators (excluding the two instances of $p y$ ), there are again 19 in the dative and 11 in the instrumental. Only a preference for the dative forms can be noted, which is normal for non-correlative causal clauses as well.

Despite the high frequency of forpam-clauses in the Old English Boethius, only a small number of them (around 15 per cent) form correlative structures. In these structures, main clause typically precedes the subordinate clause. Causal adverb of the main clause supports textual coherence by referring to the previous and the following line of argument. Particle $p e$ is used inconsistently, and only appears with one third of correlative subordinators. Dative forms of the connector are more frequent than the instrumental ones. Formed (in most cases) with one and the same connector, correlative causal clauses represent an interesting and archaic feature in the text of the Old English Boethius and in the language in general.

\section{Bibliography}

DOE 2018 - Dictionary of Old English: A to I online. Eds. Angus Cameron, Ashley Crandell Amos, Antonette diPaolo Healey et al. Toronto: Dictionary of Old English Project.

Godden, M. 1992: Literary Language. In: Hogg, Richard (ed.) The Cambridge History of the English Language. Vol. I: The Beginnings to 1066. Cambridge: Cambridge University Press.

Godden, M., Irvine, S. (eds.). 2009: The Old English Boethius. An Edition of the Old English Versions of Boethius's De Consolatione Philosophiae. 2 vols. Oxford: Oxford University Press.

Kortmann, B. 1997: Adverbial Subordination. A Typology and History of Adverbial Subordinators Based on European Languages. Berlin: De Gruyter Mouton.

Lenker, U. 2007: Forhwi 'because': Shifting deictics in the history of English causal connection. In: A. Meurman-Solin, U. Lenker (eds.). 
Connectives in the History of English. Amsterdam; Philadelphia: John Benjamins.

Lenker, U. 2010: Argument and Rhetoric: Adverbial Connectors in the History of English. Berlin: De Gruyter Mouton.

Liggins, E. 1955: The Expression of Causal Relationship in Old English Prose. Unpubl. diss. London: University of London.

Mitchell, B. 1985: Old English Syntax. Vol. I-II. Oxford: Clarendon Press.

Rissanen, M. 2011: On the long history of English adverbial subordinators. In: A. Meurman-Solin, U. Lenker (eds.). Connectives in Synchrony and Diachrony in European Languages. (= Studies in Variation, Contacts and Change in English. Volume 8). http://www.helsinki.fi/ varieng/series/volumes/08/rissanen/. 